\title{
Love, Madness and Social Order: Love Melancholy in France and England in the Late Sixteenth and Early Seventeenth Centuries
}

Michal Altbauer-Rudnik

\section{Summary}

The concept of "illness's social course" can be approached from two standpoints. We can trace both the way the social world shapes the course of an illness and the way an illness' symptoms shape the social world. The purpose of this study is to locate the specific illness of love melancholy in a specific historical and social context, namely that of France and England in the late sixteenth and early seventeenth centuries, in order to explain the intense discussion on the disorder during that period. This attempt is done with respect to the two dimensions of the concept of "illness' social course" and in the light of constructivist commentary on psychological disorders, which regards them as local stress idioms shaped by a specific social and cultural context.

Keywords: melancholy; love melancholy; Jacques Ferrand (1575-16..?); Robert Burton (1577-1640); social aetiology of melancholy

"Sweat runs down in rivers, a tremor seizes all my limbs, and paler than grass in autumn, caught by pains of menacing death, I falter, lost in the love trance." Thus does Sappho describe her unfulfilled love; it was love madness, according to the story, that drove the Greek poet to jump to her death from a Lesbos cliff. In The Thousand and One Nights both Prince Kamar and Princess

* I would like to thank Prof. Michael Heyd and Dr. Moshe Sluhovsky who commented on the draft of this paper. I am indebted to Zihriya Altbauer for her suggestions and corrections.

Michal Altbauer-Rudnik, PhD candidate, The Hebrew University of Jerusalem, P.O. Box 23594, IL-91234 Jerusalem (altbauer@yahoo.com). 
Budur went mad after being separated, he being tormented with melancholy while she became violently manic, until her father gave his consent to the match. And Shakespeare ends his tragedy about the two lovers who preferred death to living apart with the declaration that "there was never a story of more woe than this of Juliet and her Romeo". Love's torments - the suffering a lover endures due to separation from his beloved - is one of the most frequent topics in world literature. The lovesick lack all capacity or any feeling of joy and all their thoughts are focused on the unattainable love object. Whether non-consummation of this love is due to the interference of a third party or to unrequited love, the distress is often described as equivalent to mourning. But what does this infatuation, being "head over heels" in love, have in common with a physiological or psychological disorder?

In 1610 Jacques Ferrand, a French physician, published in Toulouse his Traicté de l'essence et guerison de l'amour ou de la melancholie erotique, a revised edition of which appeared in Paris in 1623. Robert Burton devoted more than a third of The Anatomy of Melancholy, published in Oxford in 1621 , to a discussion of love melancholy. The book was revised and published another four times during Burton's lifetime (in 1624, 1628, 1632 and 1638) ${ }^{1}$. Ferrand's book was translated into English and also published in Oxford in 1640. These works, as well as others of the late sixteenth and early seventeenth centuries (by Valleriola [1588], du Laurens [1597], Aubrey [1599] and de Veyries [1609], to mention just a few), though limited in length and depth, did not merely constitute a general discussion of love's torments but dealt specifically with the topic of love melancholy.

My aim in this article is to try to understand the factors underlying the extensive writing on this topic in that period, using the concept, derived from cultural psychiatry, of "illness' social course", which encapsulates the reciprocal connection between disease and society; we can trace on the one hand the way the social world shapes the course of an illness and on the other hand the way the symptoms of an illness shape the social world ${ }^{2}$. I shall try to locate the specific illness of "love melancholy" in the specific historical and social context of France and England in the late sixteenth and early seventeenth centuries, to explain the marked preoccupation with the disorder during that period and to consider the difference between the two countries ${ }^{3}$.

1 References are to Ferrand's 1623 edition and Burton's 1651 edition. Quotations from Ferrand in English are from the 1990 translation.

2 Kleinman 1995, 147-172; Ware/Kleinman 1992, 547f.; Ware 1999, 303-305.

3 While there is much popular (especially literary) discussion of love torments, historical discussion of the subject is still quite scarce. The pioneering research of John Livingston Lowes (1914) on the connection between eros and hereos in relation to love sickness in medical literature is worth mentioning here. Systematic attempts at historical discussion have been 
Attention will be paid to the two aspects of "illness' social course" and to constructivist commentary on psychological disorders, which regards them as local idioms of distress, shaped in a specific historical, social and cultural context. This thesis is offered as an alternative explanation to that of biomedical psychiatry, which tends to see mental illness as a universal disease open to positivistic research tools.

\section{Love as a disease}

The connection between love and states of illness and madness has existed since antiquity. Although the present study is focussing on the early modern period, it is useful to consider how the pathological presentation of love produced a specific medical diagnosis, since many of its features did not change in later generations ${ }^{4}$. As with all diseases, aetiological explanations of melancholy were based upon the humoural theory, according to which the human body is made up of four humours (blood, yellow bile, black bile and phlegm), each characterised by different qualities of heat and moisture, human health being the result of an optimal balance among the four. The earliest and most ordered discussions of the subject can be found in the writings of Aretaeus the Cappadocian and Galen, both of whom described the disease as a depressive illness whose symptoms, but not its aetiology, match those of melancholy. According to the Hippocratic writings the symptoms associated with melancholy include depression, fear, eating disorders, insomnia, irritability and restlessness. But whereas in melancholy the depression and fear have no apparent cause, in this case it is quite obvious, namely separation from the object of love. While the cause of melancholy is physiological and natural (an excess of black bile), the cause of love sickness is mainly emotional.

In the Middle Ages the medical view of love was not dramatically different. Oribasius, Alexander of Tralles and Paul of Aegina were among those who described the lovesick as portraying the symptoms of melancholy.

\footnotetext{
limited to the Classical and Medieval periods. For examples see Peter Toohey (1992) and the monumental research of Mary Wack (1990). In spite of the rigorous preoccupation with writing the history of madness and mental illness, the sixteenth and seventeenth centuries are still considered a "black hole" in comparison with historical discussions of later times. See also: Thomas Neely 1991, 779. While literature researcher Lawrence Babb (1951) and psychiatrist Stanley Jackson (1986) reviewed love melancholy in the sixteenth and seventeenth century in the course of their more general discussions on melancholy, in both cases discussion was limited to a review of the clinical picture of the disease without taking into account its historical and social context.

4 This is, however, not the focal point of the current paper. For more satisfying discussions, see: Babb 1951, 128-142; Jackson 1986, 356-365; Wack 1990, 3-30; Ferrand 1990, 39-97; Altbauer 2002, 12-37.
} 
The contribution of Arabic medicine in the ninth and tenth centuries was to consolidate the symptoms into the specific diagnosis of love melancholy; the clinical picture, however, remained unchanged. Although the conceptual contributions of medieval courtly love literature or of Italian Renaissance love treatises will not be dealt with here, it is important to mention their blurring of the boundaries between philosophical discussion and medical discourse, which immensely influenced the works under discussion here.

While the medical description of love melancholy in the late sixteenth and early seventeenth centuries remained faithful to its predecessors, the volume of writings increased dramatically, with such writers as Ferrand or Burton devoting hundreds of pages to its specific aetiology, symptoms, diagnosis, prognosis and, of course, therapy. Predisposition to the disease, according to the medical literature of the period, is linked to the dominance of blood (a sanguine tendency), which means the body is inclined to moisture and heat. This high level of blood in the human body was believed to produce a natural inclination to all the passions, especially erotic love. A natural inclination of the body to melancholy, however, cannot in itself bring about love melancholy. Sanguinity upsets the humoural balance of the body but does not by itself cause agony or physical distress; this can be described as the contagion stage. A beautiful object attracting attention (most specifically of the eye) is, of course, necessary to bring about the infection. Melancholy takes over only in the second stage of the disease, when for some reason the person is separated from his or her beloved and cannot consummate his or her love. The unfulfilled love dries and cools the body, causing the dominance of black melancholy bile. Excessive mental action, due to constant meditation on the love object, exacerbates the dominance of melancholy, while the emotional turmoil and the symptoms of melancholy promote the spread of black bile through the body, thus deepening despair and physical suffering.

Love melancholy has both physical and psychological symptoms, which Ferrand lists briefly (before providing details of each):

pale and wan complexion, joined by a slow fever ... palpitations of the heart, swelling of the face, depraved appetite, a sense of grief, sighing, causeless tears, irresistible hunger, raging thirst, fainting, oppression, suffocation, insomnia, headaches, melancholy, epilepsy, madness, uterine fury, satyriasis, and other pernicious symptoms ...

The medical treatment is mainly classical. After an accurate diagnosis, which can be made only by an authorised doctor, the humoural balance should be reestablished, mainly by bloodletting, but also through dietary changes and pharmaceutical prescriptions.

5 Ferrand 1990, 229. 


\section{Aetiology and cure of love melancholy}

Is this extensive writing the result of an epidemic of a disease which, like the flu, has a universal and timeless origin, or does it have unique features characteristic of the time and place? To discover an "authentic" origin, we have to peel away three "layers" of the texts. Firstly, it is worth remembering that the description of the disease is based very much upon the classical and medieval medical tradition. The writings of both Ferrand and Burton are highly eclectic and they quote, almost compulsively, hundreds of medical and literary sources. Secondly, it should be borne in mind that the therapeutic methods were not unique to love melancholy but were normative medical practice; the contrast technique, bloodletting in particular, was very common and popular at the time. Finally, there is the subjectivity "layer". Both books are filled with details chosen on account of the personal motives and life experience of their authors. A close reading of Ferrand's treatise (in particular a careful comparison of the two editions) reveals that he had to deal with criticism from both the religious establishment (the Catholic Church) and the academic establishment (his colleagues in the Paris medical faculty) ${ }^{6}$. The Anatomy is filled with biographical details about Burton, such as the fact that he was an Anglican divine and a solitary Oxford scholar and librarian, filled with fears of female nature and critical of the social and political norms of his time ${ }^{7}$. After stripping off these layers we find certain features common to the two sources, concerning aetiology and therapy, which are unique to the time and place under discussion, implying that the root causes of the disease are social. This is the focal interest of my paper.

Climate, diet and physical activity (three of the six "non-natural causes") were the main elements controlling an individual's health ${ }^{8}$. However, a reading of descriptions of the lifestyle which is most likely to lead to being infected by love melancholy makes it clear that the disease was characteristic of a specific social class. Wine, white bread, eggs, rich meats (especially white meat and stuffed poultry), nuts and most sweets were thought to be problematic. Aphrodisiac foods such as honey, exotic fruits, cakes and sweet wines were considered to be extremely dangerous ${ }^{9}$. A close look at this list reveals

6 Donald Beecher and Massimo Ciavolella, in their outstanding translation and discussion of Ferrand's treatise, throw much light on his otherwise enigmatic character; see especially Ferrand 1990, 14-38.

7 Unlike Ferrand, Burton's life story and writings have been the centre of many discussions in disciplines such as psychology, political thought, literature and gender studies, to mention just a few.

8 For a wonderfully lucid survey of the subject, see: Emch-Dériaz 1992, 134-159.

9 Burton 1651, 663f.; Ferrand 1623, 45f. 
a diet available to and typical of only the wealthy, mainly the nobility ${ }^{10}$. Sleeping in a very soft bed was also regarded as very dangerous, since it aroused lust ${ }^{11}$. Farmers were hardly likely to suffer from this problem. The writers claim that an idle lifestyle that includes excessive dining and minimal physical activity is dangerous for two reasons: first, an idle person wastes his time thinking, which dries the body and makes it melancholic; second, and much worse, idle people indulge in useless activities like plays and dances that involve both men and women and thus induce lust. "[The disease] is most evident among such as are young and lusty, in the flower of their years, nobly descended, high-fed, such as live idly, and at ease," writes Burton ${ }^{12}$. He scornfully examines the lifestyle of the nobility, which gives rise to burning desire, and hence to love melancholy. Ferrand, though not as directly critical, emphasises the same factors and writes that "great lords and ladies are more inclined to this malady than the common people" ${ }^{13}$. Class difference, formerly only hinted at in the discussion on diet, becomes the major issue. But are young aristocratic men and women, who obviously eat and sleep better than most, more inclined to this disease by reasons of their lifestyle, or is there another cause for their distress?

Having dealt with the various therapeutic techniques, Ferrand declares: "No physician would refuse to someone suffering from erotic mania or melancholy the enjoyment of the object of desire in marriage, in accordance with both divine and human laws, because the wounds of love are cured only by those who made them." ${ }^{14}$ Although Ferrand only deals quite briefly with this type of remedy (compared to the dozens of pages he devotes to medical therapies), he is also quite decisive. Only by union with the beloved will the patient be healed completely; but this can be achieved only in accordance with divine and human rules. In his chapter on love melancholy in married couples, Ferrand is obviously fully aware that these rules are in many cases the cause of youthful distress. Acknowledging that marriage is not a guarantee against the disease, he admits that love melancholy in married couples is usually the result of the animosity arising in a couple that was forced to marry and consequently sought love outside the marriage bonds ${ }^{15}$.

10 Andrew Appleby has pointed out that malnutrition was, in the early modern period as much as today, often a consequence of an affluent society, characterised by an increased intake of sugar and animal fats; see: Appleby 1979, 97-105.

11 Ferrand 1623, 47.

12 Burton 1651, 657.

13 Ferrand 1990, 232.

14 Ferrand 1990, 334.

15 Ferrand 1623, $210 f$. 
Burton concludes that "the last and best cure [for the lovesick] is to let them have their desire and enjoy one another" ${ }^{\prime 16}$. However, unlike Ferrand, who deals rapidly with the subject, Burton directly attacks the legal and social obstacles that prevent a young couple from being joined in marriage. He criticises the parents, teachers and guardians who withhold their consent to a match because of limitations imposed by law and custom, especially on account of inequality of status between the lovers. He deplores an "iron age" that respects "riches alone", and condemns the cruelty of parents who cause great despair by forcing arranged marriages on their children. Revealing an interesting sense of the change that time can bring about, Burton states that the parents' mistake consists in judging the situation solely in the terms and by the standards of their own time and thinking that their children too should remain untouched by emotion ${ }^{17}$. It is apparently not only the lifestyle of aristocratic youth that inclines them to love melancholy ...

Thus far we have established that the medical discourse appears to be common to the two countries. In what follows we shall look beyond the medical literature and consider the social aspects of love and marriage in France and England in the late sixteenth and early seventeenth centuries.

\section{Pathologies of love and their social background}

Trying to analyse the psychological disorder of an early period is not an easy task because we lack an essential element, namely the direct observation of human behaviour. Moreover, medical literature tends to be based mainly on an earlier medical tradition; Burton himself lacked any experience in medical practice, while Ferrand gives only three case descriptions, only one of which concerns a young man suffering from love melancholy. In my search for occurrences of the disorder outside the medical literature I have turned to both the diaries of healers and contemporary literature, although here I can only present my findings briefly, with minimal references. While these literary examples are fictional, existing only on stage or in books, they can be taken as reflecting the interests of audiences, their types of distress and their ideals.

French literature includes many men and women whose unrequited love drives them to act unnaturally or commit suicide. A good place to start is with the sonnets of Louise Labé, the poet from Lyons, which provide a good 
example of love torments; her detailed descriptions of the physical and psychological misery entailed in unfulfilled love are similar to those of the medical texts, while the sonnets themselves provide autobiographical evidence. Labé was forced to marry a ropemaker twenty years her senior in order to keep her family's business intact. Her heart, however, belonged to one of the soldiers of the royal guard stationed in Lyons ${ }^{18}$. Similarly, Pierre de l'Estoile, a French parlementaire, mentions in his diary of 1593 that his niece, a girl of twenty, died in Paris only twenty-four hours after being locked up to prevent her marrying a young man of a lower rank ${ }^{19}$. In 1609 l'Estoile commented that in matters of marriage "mothers and fathers think only about money and are not attentive to any other consideration" ${ }^{20}$. French drama of the early seventeenth century immortalised the submission to family authority and the social order expected of aristocratic youth, as is clearly demonstrated by the adaptations of historical themes, such as Corneille's Médée or Le Cid. This attitude is exemplified in a short essay by Joyeux entitled Dialogue de l'amour et de la raison; Reason defends the patriarchal rights of the father over his children, especially concerning marriage, while Love maintains that the choice of a marriage partner should be free and in accordance with the heart's inclinations. The essay ends with the triumph of Reason over Love, in view of the threat of violence and disorder entailed by yielding to love ${ }^{21}$.

English medical practice provides an abundance of love victims. Almost forty per cent (about eight hundred men and women in all) of the patients of Richard Napier, a healer practising in Linford, attributed their distress to unrequited love. Napier himself describes several cases, one being that of a young man who threatened to poison himself if barred from marrying one of the household servants ${ }^{22}$. However, in none of these cases is there any evidence of an organic disease, neither does the term "love melancholy" appear. The term is likewise absent from the detailed diaries of their practice kept by John Symcotts, Dr. Barker of Shrewsbury and Joseph Binns.

One of the most notable cases of its time was that of King James I's cousin Arabella Stuart, who became secretly engaged in 1610 to William Seymour, a young Oxford scholar; James opposed the match on the grounds that it was unbecoming to the young lady's distinguished lineage, yet the couple nevertheless married. They were arrested at the end of the ceremony but managed to escape and reach the French coast, where they were again arrested, brought back to England and imprisoned. Arabella thereafter refused all sustenance

18 On Labé's life and love affair, see: Cameron 1990,17-26.

19 Estoile 1875-1896, VI 108.

20 Estoile 1875-1896, VIII 251f.

21 Joyeux 1667, 1-23.

22 MacDonald 1981, 88f. 
and died in the Tower of London in $1615^{23}$. Stories of this kind were the object of particularly great popular interest in Elizabethan and early Stuart literature, and the plays of Marlowe, Shakespeare, Ford and Webster, as well as the metaphysical poems of Donne, Herbert and Marvel, deal overwhelmingly with the theme of love, with despair playing a huge role. Lawrence Babb has claimed that the term "melancholy" in relation to love appears with unprecedented frequency in Elizabethan literature ${ }^{24}$. The titles of John Ford's plays (The Lover's Melancholy, The Broken Heart and Love's Sacrifice) exemplify this point; they all describe the obstacles to fulfilling love placed by society in the way of young men and women. Webster's Duchess of Malfi and dozens of Shakespeare's characters likewise exhibit clearly all the physical and psychological symptoms of the tormented lover.

Although none of these examples from the French and English literature of the period refer to love melancholy as a separate medical diagnosis, they do provide evidence of the prevalence of a pathological dimension to love in that era. They all highlight the distress resulting from parental limitation on the romantic individual choice of a marriage partner. But is this impression based on a real social distress? A series of edicts and ordinances from the mid-sixteenth to the mid-seventeenth centuries entirely altered family law in France, notably laws concerning marriage. In 1556 Henri II published an edict outlawing clandestine marriages - i.e. those contracted secretly without parental consent - and raised the age of consent from 20 to 30 for men and from 17 to 25 for women. In a 1579 ordinance Henri III declared that both a couple who married clandestinely and those who gave them assistance would be guilty of a crime for which the penalty could be banishment or even execution. An additional edict in 1629 repeated the same principles "in order to maintain the authority of fathers over their children". In 1639 Louis XIII reaffirmed the previous orders and declared that all children were to be considered as under the age of consent, regardless of sex or actual age, and that any couple wishing to get married had to provide signed parental consent and detailed family documents certifying their class and residence. The purpose of this legislation was not just to maintain social order in a period of growing centralisation and to try to remove one of the Catholic Church's last strongholds. It served the interests of both the traditional noblesse d'épée and the growing noblesse de robe, who not only wanted to enhance their families' fortunes but were also concerned to keep their political, social and economic rights and privileges, which were threatened if young people were free to choose a marriage partner. The legislation was the result of pressures on the

23 Durant 1978.

24 Babb 1951, 145-174, especially 157. 
crown, both from inside the court and in the Paris parlement, that constituted what historian Sarah Hanley calls a "family-state compact". Interestingly, the first edict was a royal solution to a family crisis in the noble family of Montmorency, which involved a clandestine marriage ${ }^{25}$. Despite some geographical and class variability, it is important to remember that due to centralising tendencies and the fact that these were royal edicts, the patriarchal system remained entrenched for many generations.

Given that the situation in England appears to have been quite different, Burton's criticism may seem somewhat exaggerated. In accordance with common law, marriages were considered legal, even if clandestine, as long as the couple had reached the age of consent. Though the king could oppose marriages, the court was considered a place of refuge from parental authority, where young noblemen and women could follow the promptings of their hearts, with the king's blessing. In practice, however, young people were exposed to pressure from their parents. The period of English history between 1560 and 1640 was an extraordinary one as concerns family discipline relating to marriage. Even though parents did not have any lawful or moral rights, they had social and, more importantly, financial power over their children, which rendered the matter more complex than would appear from a presentation in terms of a dichotomy opposing free choice and arranged marriages. The more financially dependent the children were on their parents, the more restricted was their freedom to choose a partner. Many social historians of England of the period agree that as you go down the social scale, you find a greater freedom of choice based more often on mutual affection ${ }^{26}$. The aristocracy, the urban elite and the gentry, however, were most liable to be infected by love melancholy, as marriage was too important an issue, socially and financially, to be left entirely to the whims of the young. On this issue historians tend to agree with Lawrence Stone, who claimed that England at that time was a patriarchal authoritarian society, driven by "parental absolutism" "27; it was a society in which the choice of a partner was made entirely by the parents, and in which most of the marriage arrangements were between families of the same socioeconomic status. Nevertheless, Stone claimed that only a small minority were affected by or experienced the ideal of romantic love which started to dominate the literature from the late six-

25 Hanley 1987, 55 f.

26 See for example Macfarlane 1986, 5-18; Houlbrooke 1984, 68-73; Wrightson 1983, 81-86; Quaife 1979, 243-249; Sharp 1985, 69-90.

27 Stone 1966, 38; 1977, 5, 60,178-180. Other aspects of Stone's theory, however, especially the way he generalised his conclusions without much consideration of geographical and especially socioeconomical diversity, have frequently been criticised; see for example Anderson 1980, 39-64; Andrew 1989, 381-385; Houlbrooke 1984, 14f.; Macfarlane 1979, 103-126. 
teenth century. I believe that Stone underestimated the value of literature as reflecting and even shaping reality. Burton himself claimed that reading love stories could give rise to the malady and was therefore very dangerous ${ }^{28}$. It might not be so far-fetched to claim that in an age when literature gave rise to romantic ideals which many lower-ranking young people could fulfil, the lack of parental consent could be an additional trigger inciting young aristocratic men and women to follow their hearts. This point is especially interesting in light of Ferrand's comment that in some cases permission to consummate love, and not the consummation itself, was enough to reduce the symptoms of love melancholy ${ }^{29}$. It is nonetheless important to pay attention to those who opposed arranged marriages, mainly because of the influence of Puritan ideas, according to which a husband is committed to loving his wife and should thus marry only out of true affection. The Puritan standpoint influenced Anglican preachers such as Jeremy Taylor and of course Robert Burton.

In the light of the English evidence I would suggest that, unlike in France where emotional distress was more intensely felt and the medical diagnosis was therefore a direct way of using rational tools to deal with it, in England the adaptation of such methods was part of an already existing criticism of attempts to stand in the way of young lovers.

\section{Conclusion}

In one of his articles, the late historian Roy Porter examined the appearance in early modern times of the concept of psychogenesis of the family, according to which the family is one of the main and perhaps the most influential causes of personality disorders (a very common concept among the antipsychiatric movement of the sixties) ${ }^{30}$. I believe that the medical and nonmedical evidence regarding love melancholy offers further proof of Porter's thesis, since it shows that both the core of the distress in love melancholy and its solution can be found within family relations and the social order, and that love melancholy is not a physiological disease per se that can be cured by a little bloodletting. Both Ferrand and Burton were well aware of the social origin of the disease. In my opinion, the two writers' different presentation of the subject corresponds to the social realities in their respective countries as well as their literary styles. It is not surprising that as the limitations on

28 Burton 1651, 695.

29 Ferrand 1623, $205 f$.

30 Porter 1998. 
love are more strictly enforced it becomes harder to find contemporary literary examples and more convenient, as in France, to deal with the problem as a medical one and to suggest surgical and pharmaceutical therapies.

Psychologist Stanton Peele has suggested looking at Romeo and Juliet as the prototype of a love story which includes all the personal and social parameters that could lead to love addiction ${ }^{31}$. Such an approach, which can often be seen in modern productions of the play, is an attempt to separate the plot from its unique social context and turn its specific psychological elements into universal and timeless ones. The connection between love, sickness and madness has a long history and is not unique to Western culture, which means that there is a certain universal and timeless dimension to love sickness. Yet it would appear that the consolidation of a specific disease in a specific context is culturally determined. Some of the features of love melancholy in late-sixteenth- and early-seventeenth-century France and England were unique to a specific chronologically limited social context and served as techniques to deal with specific social distress, as I hope I have been able to demonstrate.

Furthermore, in light of the evidence, one can speculate that love melancholy in the late sixteenth and early seventeenth centuries, especially in England, was a sort of idée force, that its prevalence and popularity increased so much that it started to shape contemporary social reality, meaning that it could even contribute to the development of the English notion of romantic love. In my opinion there is an intermediate path between this viewpoint and belief in the universal nature of diseases. While recognising the universal and timeless nature of love melancholy, which was traditionally more physiological and is now more psychological in nature, one should acknowledge the cultural component of a disease which both shaped society and was shaped by it.

\section{Bibliography}

Altbauer, Michal, Love Melancholy in France and England in the Late Sixteenth and Early Seventeenth Centuries [MA Thesis Submitted to The Hebrew University of Jerusalem] (Jerusalem 2002) [in Hebrew]

Anderson, Michael, Approaches to the History of the Family, 1500-1914 (London 1980)

Andrew, Donna T., "Marriage History as Social History", Canadian Journal of History 24 (1989) 381-385

Appleby, Andrew B., "Diet in Sixteenth Century England: Sources, Problems, Possibilities", in: Charles Webster (ed.), Health, Medicine and Mortality in the Sixteenth Century (Cambridge 1979) 97-116

31 Peele 1988, 168f. 
Aubrey, Jean, L'antidote d'amour (Paris 1599)

Babb, Lawrence, The Elizabethan Malady (East Lansing 1951)

Burton, Robert, The Anatomy of Melancholy (Oxford 1651)

Cameron, Keith, Louise Labé: Renaissance Poet and Feminist (New York 1990)

Du Laurens, André, Discours de la conservation de la veue, des maladies mélancoliques, des catarrhes et de la vieillesse (Paris 1597)

Durant, David N., Arabella Stuart (London 1978)

Emch-Dériaz, Antoinette, "The Non-Naturals Made Easy", in: Roy Porter (ed.), The Popularization of Medicine, 1650-1850 (London and New York 1992) 134-159

Ferrand, Jacques, De la maladie d'amour ou mélancholie erotique (Paris 1623)

- A treatise of Lovesickness translated and edited with an introduction by Donald A. Beecher and Massimo Ciavolella (Syracuse 1990)

Hanley, Sarah, "Family and State in Early Modern France: The Marriage Pact", in: Marilyn J. Boxer/Joan W. Scott (eds), Connecting Spheres (New York/Oxford 1987) 53-63

Houlbrooke, Ralph A., The English Family, 1450-1700 (London/New York 1984)

Jackson, Stanley W., Melancholia and Depression (New Haven/London 1986)

Joyeux, François, Traité des combats que l'amour a eu contre la raison et la jalousie (Paris 1667)

Kleinman, Arthur, Writing at Margin (Berkeley 1995)

de L'Estoile, Pierre, Mémoires-Journaux (Paris 1875-1896)

Lowes, John Livingston, "The Lovers Maladye of Hereos", Modern Philology 11 (1914) 491-546

MacDonald, Michael, Mystical Bedlam (Cambridge 1981)

Macfarlane, Alan, "The Family, Sex and Marriage in England, 1500-1800, by L. Stone: A Review Essay", History and Theory 18 (1979) 103-126

- Marriage and Love in England: Modes of Reproduction, 1300-1840 (Oxford 1986)

Peele, Stanton, "Fools for Love:The Romantic Ideal, Psychological Theory and Addictive Love", in: Robert J. Sternberg/Michael L. Barnes (eds), The Psychology of Love (New Haven/ London 1988) 159-188

Porter, Roy, "Madness and the Family before Freud: The View of Mad-Doctors", Journal of Family History 23 (1998) 159-172

Quaife, Geoffrey Robert, Wanton Wenches and Wayword Wives (New Brunswick 1979)

Sharp, James A., "Plebian Marriages in Stuart England: Some New Evidence from Popular Literature", Transactions of the Royal Historical Society (1985) 69-90

Stone, Lawrence, "Social Mobility in England, 1500-1700", Past and Present 33 (1966) 16-55

- Family, Sex and Marriage in England: 1500-1800 (London 1977)

Thomas Neely, Carol, "Recent Works in Renaissance Studies: Psychology: Did Madness Have a Renaissance?”, Renaissance Quarterly 44 (1991) 776-791

Toohey, Peter, "Love, Lovesickness and Melancholia", Illinois Classical Studies 17 (1992) 265-286

Valleriola, François, Observationum medicinatium, libri sex (Lugduni 1588)

de Veyries, Jean, La généalogie de l'amour divisée en deux livres (Paris 1609)

Wack, Mary F., Lovesickness in the Middle Ages (Philadelphia 1990)

Ware, Norma, "Toward a Model of Social Course in Chronic Illness", Culture, Medicine and Psychiatry 23 (1999) 303-331

- AArthur Kleinman, "Culture and Somatic Experience", Psychosomatic Medicine 54 (1992) 546-554

Wrightson, Keith, English Society: 1580-1680 (London 1983) 